DEPARTMENT OF THE INTERIOR

U.S. GEOLOGICAL SURVEY

\title{
MAP AND GEOTECHNICAL PROPERTIES OF SURFACE MATERIALS OF THE CULPEPER BASIN AND VICINITY, VIRGINIA AND MARYLAND
}

By A. J. Froelich

MISCELLANEOUS INVESTIGATIONS SERIES

Published by the U.S. Geological Survey, 1985 